\title{
Negative-Binomial and Quasi-Poisson regressions between COVID-19, mobility and environment in São Paulo,
} Brazil

Sergio Ibarra-Espinosa

Departamento de Ciências Atmosféricas, Instituto de Astronomia, Geofísica e Ciências Atmosféricas, Universidade de São Paulo, Brazil

Edmilson Dias de Freitas

Departamento de Ciências Atmosféricas, Instituto de Astronomia, Geofísica e Ciências Atmosféricas, Universidade de São Paulo, Brazil

Karl Ropkins

Institute for Transport Studies, University of Leeds, UK

Francesca Dominici

Harvard Data Science Initiative, Harvard University, Boston, MA 02138, USA

Amanda Rehbein

Departamento de Ciências Atmosféricas, Instituto de Astronomia, Geofísica e Ciências Atmosféricas, Universidade de São Paulo, Brazil

\section{Corresponding author}

Sergio Ibarra-Espinosa

Departamento de Ciências Atmosféricas, Instituto de Astronomia, Geofísica e Ciências Atmosféricas, Universidade de São Paulo, Brazil

Phone +55 (11) 934909778

E-mail: sergio.ibarra@usp.br 
medRxiv preprint doi: https://doi.org/10.1101/2021.02.08.21250113; this version posted August 3, 2021. The copyright holder for this preprint (which was not certified by peer review) is the author/funder, who has granted medRxiv a license to display the preprint in perpetuity.

It is made available under a CC-BY 4.0 International license .

\title{
Negative-Binomial and Quasi-Poisson regressions between COVID-19, mobility and environment in São Paulo,
}

\section{Brazil}

Sergio Ibarra-Espinosa ${ }^{1}$, Edmilson Dias de Freitas ${ }^{1}$, Karl Ropkins $^{2}$, Francesca Dominici ${ }^{3}$, Amanda Rehbein ${ }^{1}$

${ }^{1}$ Departamento de Ciências Atmosféricas, Instituto de Astronomia, Geofísica e Ciências Atmosféricas, Universidade de São Paulo, Brazil

${ }^{2}$ Institute for Transport Studies, University of Leeds, UK

${ }^{3}$ Harvard Data Science Initiative, Harvard University, Boston, MA 02138, USA

Author correspondence: sergio.ibarra@usp.br

\begin{abstract}
Brazil, the country most impacted by the coronavirus disease 2019 (COVID-19) on the southern hemisphere, use intensive care admissions per day, mobility and other indices to monitor quarantines and prevent the transmissions of SARS-CoV-2. In this study we quantified the associations between residential mobility index (RMI), air pollution, meteorology, and daily cases and deaths of COVID-19 in São Paulo, Brazil. We applied a semiparametric generalized additive model (GAM) to estimate: 1) the association between RMI and COVID-19, accounting for ambient particulate matter $\left(\mathrm{PM}_{2.5}\right)$, ozone $\left(\mathrm{O}_{3}\right)$, relative humidity, temperature and delayed exposure between 3-21 days, and 2) the association between COVID-19 and exposure to for ambient particulate matter $\left(\mathrm{PM}_{2.5}\right)$, ozone $\left(\mathrm{O}_{3}\right)$, accounting for relative humidity, temperature and mobility. We found that an RMI of $45.28 \%$ results in 1,212 cases (95\% CI: 1,189 to 1,235 ) and 44 deaths (95\% CI: 40 to 47 ). Increasing the isolation from $45.28 \%$ to $50 \%$ would avoid 438 cases and 21 deaths. Also, we found that an increment of $10 \mu \mathrm{g} \cdot \mathrm{m}^{-3}$ of $\mathrm{PM}_{2.5}$ results in a risk of 1.140 (95\% CI: 1.021 to 1.274) for cases and 1.086 (95\% CI: 1.008 to 1.170$)$ for deaths, while $\mathrm{O}_{3}$ produces a relative risk of 1.075 (95\% CI: 1.006 to 1.150 ) for cases and 1.063 (95\% CI: 1.006 to 1.124) for deaths, respectively. We compared our results with observations and literature review, finding well agreement. Policymakers can use such mobility indices as tools to control social distance activities. Spatial distancing is an important factor to control COVID-19. Small increments of air pollution result in an increased number of COVID-19 cases and deaths.
\end{abstract}

Keywords: COVID-19, SARS-CoV-2, residential mobility index, air pollution, meteorology 
medRxiv preprint doi: https://doi.org/10.1101/2021.02.08.21250113; this version posted August 3, 2021. The copyright holder for this preprint (which was not certified by peer review) is the author/funder, who has granted medRxiv a license to display the preprint in perpetuity.

It is made available under a CC-BY 4.0 International license.

Funding: E.D.F. efforts were supported by São Paulo Research Foundation (FAPESP) Grants (N. 2015/03804-9 and 2016/18438-0); A.R. efforts were also supported by FAPESP Grant (N. 2016/10557-0); S.I.E efforts were also supported by FAPESP Grant (№. 2021/07136-1). Authors also thank "Coordenação de Aperfeiçoamento de Pessoal de Nível Superior - Brasil" (CAPES) Finance Code 001. All data used in this study comes from open data available online, mentioned in the manuscript. 
medRxiv preprint doi: https://doi.org/10.1101/2021.02.08.21250113; this version posted August 3, 2021. The copyright holder for this preprint (which was not certified by peer review) is the author/funder, who has granted medRxiv a license to display the preprint in perpetuity.

It is made available under a CC-BY 4.0 International license .

\section{Introduction}

The world has been facing an unprecedent critical health crisis due to COVID-19 pandemic caused by the severe acute respiratory syndrome coronavirus 2 (SARS-CoV-2). According to the Johns Hopkins University (JHU) Center for Systems Science and Engineering (CSSE), on February 20 ${ }^{\text {th }}$ 2021, there were 110,810,601 confirmed cases of COVID-19 worldwide, and 2,454,047 deaths (Dong et al. 2020). Many countries implemented social isolation and quarantine strategies, while internet companies released anonymized aggregated location data to provide information on the effectiveness of quarantine and isolation (Google 2021). This new disease demonstrated that developed countries such as Belgium, Italy, and Spain were unprepared, which resulted in infection fatality rates (deaths/cases) of $15.4 \%, 13.5 \%$, and $10.2 \%$, respectively. Furthermore, new mutations of SARS-CoV-2 would present higher transmissibility and current vaccines might not offer protection against it (Gupta et al. 2021; Kupferschmidt 2021). Therefore, it is urgent and crucial to conduct more research to better understand the relationships and associations between SARS-CoV-2 transmissibility and environmental factors.

COVID-19 spread very quickly across Latin America (Bolaño-Ortiz et al. 2020; Tello-Leal and Macías-Hernández 2020). As of January 4, 2021, Brazil, with an area of 8.5 million $\mathrm{km}^{2}$ and a population of 208 million, is the third country with more cases $(7,733,746)$ and deaths $(196,018)$ (Dong et al. 2020). The city of São Paulo, the most populated city in Brazil with 11.8 million inhabitants (IBGE 2020), presents the highest number of COVID-19 cases $(404,025)$ and deaths $(15,725$, https://covid.saude.gov.br/). In Brazil, only symptomatic cases are tested, hence, the real number of SARS-CoV-2 infections could be much higher. A recent study shows that COVID-19 death notification in Brazil is underreported (Alves et al. 2020). On March 24 2020 (GESP 2020), São Paulo's government recommended social distancing for suspected cases and introduced a local quarantine to reduce virus transmission. Brazil adopted containment measures such as close contact and limited mobility as protective measures, however "quarantine" was the official term used by São Paulo state government. Consequently, air pollution levels dropped during the quarantine. For instance, the concentrations of carbon monoxide $(\mathrm{CO})$, nitrogen dioxide $\left(\mathrm{NO}_{2}\right), \mathrm{PM}_{10}$, and $\mathrm{PM}_{2.5}$ were reduced by $-35.70 \%,-29.56 \%,-17.80 \%$, and $-25.02 \%$, respectively, while $\mathrm{O}_{3}$ increased by $53.25 \%$ between 21:00-03:00 Local Time (LT) (Dantas et al. 2020; Freitas et al. 2020; Nakada and Urban 2020). Other studies showed reductions in China (30\% of $\mathrm{NO}_{2}$ and $25 \%$ of $\mathrm{CO}_{2}$ ) (Dutheil et al. 2020). However, there are indications that COVID19 and air pollution interactions may be more complex. Some early reports suggest that longer-term exposure to air pollution increases susceptibility and severity upon infection (Tosepu et al. 2020; Wu et al. 2020). Similarly, 
medRxiv preprint doi: https://doi.org/10.1101/2021.02.08.21250113; this version posted August 3, 2021. The copyright holder for this preprint (which was not certified by peer review) is the author/funder, who has granted medRxiv a license to display the preprint in perpetuity.

It is made available under a CC-BY 4.0 International license .

meteorological interactions are likely to be important, for example, some studies have suggested that high humidity and temperature would reduce virus transmission (Wang et al. 2020a, 2020b). Furthermore, the biological inactivation rate of SARS-CoV-2 is sensitive to humidity, with minimum half-life at $65 \%$ and higher at $40 \%$ and $85 \%$, and its decays at $27{ }^{\circ} \mathrm{C}$ is 10 times faster than at $10^{\circ} \mathrm{C}$ (Morris et al. 2020). However, estimations for the Amazonian city of Manaus, which have a climatology ${ }^{1}$ temperature $27^{\circ} \mathrm{C}$ of and relative humidity $80.2 \%$ for July, show that between $44 \%$ and $66 \%$ of the population was infected with SARS-CoV-2 by July (Buss et al. 2020). Then, more research is needed to better understand the interactions between SARS-COV-2 and environmental factors.

Some studies have evaluated the effect of mobility on COVID-19, mainly in China. Kraemer et al., (2020) found correlation of 0.94 between real-time mobility data and COVID-19 cases from Wuhan, China, confirming the exportation of cases from Wuhan to other provinces and the effectiveness of the sanitaire cordon. Tian et al (2020) found that Wuhan shutdown delayed the appearance of COVID-19 in 2.9 days. Zhu et al (2020b) found that increasing the human mobility increased $6.45 \%$ daily confirmed cases. In the US, Badr et al (2020) associated county-level origin-destination matrices and COVID-19 cases finding that counties with more mobility presented higher number of cases. In a related correspondence, Gatalo et al (2020) found that the absence of a strong correlation between growth of cases and mobility may be related to other factors, such as wearing mask, keeping distance in encounters and also, the existence of superspreading events.

Our study investigates the associations between RMI and COVID-19, and air pollution and COVID-19 on a particular day, having accounted for environmental and meteorological factors. We analyzed the effects of mobility, air pollution, and meteorology on the daily COVID-19 cases and deaths in the city of São Paulo. We applied semiparametric generalized additive models to study the effect of each predictor by isolating confounding factors (Peng and Dominici 2008). To the best of our knowledge, few studies have associated mobility air pollution, meteorological factors, and COVID-19 simultaneously especially in Latin America.

\section{Material and Methods}

The Brazilian Ministry of Health reports the official daily time-series of cases and mortality associated with COVID19 at https://covid.saude.gov.br/ updated once a day around 19:00 Brazilian official time (-3 GMT). This information is gathered from the 26 states and the federal district health secretaries and provided at the national, state, and

${ }^{1}$ Climatology between 1981-2010 https://portal.inmet.gov.br/ 
medRxiv preprint doi: https://doi.org/10.1101/2021.02.08.21250113; this version posted August 3, 2021. The copyright holder for this preprint (which was not certified by peer review) is the author/funder, who has granted medRxiv a license to display the preprint in perpetuity.

It is made available under a CC-BY 4.0 International license .

municipality levels. The availability of data using the web site was interrupted on June $07^{\text {th }}, 2020$, and returned on June $08^{\text {th }}, 2020$ after judicial demand (G1 2020). When returned, it included the data obtained when the web site was offline. To check the trustworthiness of that data, we compared it with the dataset from BrasilIO (https://brasil.io/covid19/). The BrasillO is an independent organization made of voluntaries that also gathers COVID19 data from state health secretaries. Both datasets are very similar, in effect, we applied the Wilcoxon test (R Core Team 2021) for cases and deaths getting p-values of 0.7798 and 0.922 , meaning that there are no significant differences between the two datasets. Therefore, we used the official data from the Brazilian Ministry of Health. The day July $29^{\text {th }}$ the number of cases reported included July $28^{\text {th. }}$; therefore, we distributed the number of cases and deaths equally in both days. Figure 1shows the daily cases and deaths from COVID-19 in São Paulo State between March 27 $7^{\text {th }}, 2020$ and January $03^{\text {rd }}, 2021$. The daily mean cases are 1432 and deaths is 55 , with a maximum of 7063 on August $13^{\text {rd }}$, 2020 and 179 on June $23^{\text {rd }}, 2020$, respectively. Furthermore, the variances are 1511183 for cases and 1889.89 for deaths, indicating overdispersion in the data. In effect, the dispersion parameter for cases is 1035.86 and for deaths 33.84 (both p-value<0.05) (Kleiber and Zeileis 2008).

We obtained mobility datasets from Google mobility trends (Google, 2020) and the Intelligent Monitoring System for the city of São Paulo (SIMI-SP). The Google data is based on the use of smart devices such as cellphones, vehicle trackers, and other GPS enabled systems ${ }^{2}$. The data reported by Google consists in mobility trends related to places as percentage change from baseline, with baseline as the median value, for each day of the week, during the 5-week period January $3^{\text {rd }}$ and February $6^{\text {th }}, 2020$. We selected the mobility trend "residential", because it better represent the situation of spatial isolation (Hereafter Residential Mobility Index, RMI), then, higher values of RMI means higher isolation. The SIMI-SP data is collected by network companies which receive cellphone triangulating signals with the nearest cellphone communication tower ${ }^{3}$. This means that SIMI-SP does not need internet to collect mobility information. Both indices are shown on Figure 2, meaning that higher values represent more stay-at-home and while lower values pre-quarantine conditions. RMI is an indicator that represent exposure in two ways, first, staying out of home increases the chances of getting infections with SARS-CoV-2 present in aerosols (Morawska and Milton 2020) and second, increases the exposure to air pollution with deleterious effect on human health which could pose a synergetic effect. The trend on both RMI shows steady decline ahead of the start of quarantine on March $24^{\text {th }}, 2020$

\footnotetext{
${ }^{2}$ https://www.google.com/covid19/mobility/
} 
medRxiv preprint doi: https://doi.org/10.1101/2021.02.08.21250113; this version posted August 3, 2021. The copyright holder for this preprint (which was not certified by peer review) is the author/funder, who has granted medRxiv a license to display the preprint in perpetuity.

It is made available under a CC-BY 4.0 International license .

(black vertical line) (GESP 2020). The median RMI for Google data $13.51 \%$ and for RMI SIMI-SP is $44.75 \%$ for the whole period. The median RMI for the pre-quarantine period (first 15 days of March 2020), are $-1 \%$ for Google and $31.30 \%$ for SIMI-SP and after the quarantine $14 \%$ for Google and $45.48 \%$ for SIMI-SP.

Air pollution and meteorology hourly surface measurements were obtained from the air quality system (QUALAR) operated by the Environmental Agency of Sao Paulo State (CETESB, 2020). QUALAR archives air quality real-time data using several stations spread in São Paulo. Hourly averages of $\mathrm{O}_{3}\left(\mathrm{ug} / \mathrm{m}^{3}\right), \mathrm{PM}_{2.5}\left(\mathrm{ug} / \mathrm{m}^{3}\right)$, relative humidity (\%) and temperature $\left({ }^{\circ} \mathrm{C}\right)$ are shown in Figure 3, between January $01^{\text {st }}$, 2019 and January $4^{\text {th }}$, 2021. Locally estimated scatterplot smoothing (or local regression LOESS) show that that the $\mathrm{O}_{3}$ incremented after the quarantine and remained higher than 2019 during most of 2020. The concentrations of PM2.5 during 2020 were lower than 2019, related to the decrease in human activity and also, as reported by other studies (Bolaño-Ortiz et al. 2020; Debone et al. 2020; Nakada and Urban 2020), and just in September concentration increased. The quarantine beginning coincided with the dry season beginning at São Paulo, presenting a decline in temperature compared to the early months of 2020. The most significant feature of the São Paulo dry season (April to November), the wet season counterpart (Vera et al. 2006), is the non-significative precipitation amount, caused by weak isolated events, and long periods with no precipitation occurring in between (Rehbein et al. 2018), and the very low relative humidity during the daytime (climate reports from the Climate Group of Studies - GrEC/USP, http://www.grec.iag.usp.br). Also, a general decreasing in temperature occurs according to the austral winter and presenting drops in temperature, associated to the synoptic systems crossing São Paulo and generally are not able to organize convection (GrEC/USP, http://www.grec.iag.usp.br) or even sea breezes that eventually reaches the interior of São Paulo (Freitas et al. 2007). In 2020, for instance, from April $3^{\text {rd }}$-May $3^{\text {rd }}, 2020$ there was very few (2 mm at São Paulo-SESC Interlagos station, in the south of São Paulo) or no precipitation (at the São Paulo-Mirante de Santana station, in the north of São Paulo) according to the official meteorological stations (www.inmet.gov.br), while synoptic systems (such as cold fronts) were observed (CPTEC/INPE, https://www.cptec.inpe.br; GrEC/USP, http://www.grec.iag.usp.br). The first semester of 2020 was drier and colder than 2019, but during the second semester, relative humidity and temperature remained similar.

Association between mobility and COVID-19

The statistical analyses consisted of the application of the generalized additive model (GAM) (Hastie and Tibshirani 1990). One of the most common applications of this framework consists of a semi-parametric model in environmental studies to understand the associations between air pollution and health outcomes by controlling other factors such as 
medRxiv preprint doi: https://doi.org/10.1101/2021.02.08.21250113; this version posted August 3, 2021. The copyright holder for this preprint (which was not certified by peer review) is the author/funder, who has granted medRxiv a license to display the preprint in perpetuity.

It is made available under a CC-BY 4.0 International license .

meteorology (Dominici et al. 2004; Peng and Dominici 2008). Recently, a study has shown that air pollution can increase up to $15 \%$ of COVID-19 mortality and worldwide, $27 \%$ in East Asia, $19 \%$ in Europe and 17\% in North America (Pozzer et al. 2020). It has been shown that health effects of air pollution is related to previous days' exposure (Abrutzky et al., 2013; Carracedo-Martínez et al., 2010; Leitte et al., 2009). In this study we need to consider the incubation period for COVID-19, that is the period of time between the exposure to SARS-CoV-2 and the symptom onset. Furthermore, in this study we want to characterize how the exposure, measured by the mobility indices, is associated with COVID-19. It has been reported that the incubation period for COVID-19 is 5.1 days (95\% CI, 4.5 to 5.8 days (Kraemer et al. 2020; Lauer et al. 2020), Lai et al (2020) found between 2 and 14 days with a mean of 6.4 days another (Lai et al. 2020). Therefore, we calculated moving averages between 4 and 21 days of mobility and environmental factors, and study possible associations with COVID-19. We used thin plate splines for accounting confounding factors of $\mathrm{PM}_{2.5}, \mathrm{O}_{3}$, temperature, relative humidity, day of the week and time, including interactions between the variables with quasi-poisson and negative binomial distributions to capture over-dispersion (Wood 2017; Zeileis et al. 2008). For instance, tropospheric $\mathrm{O}_{3}$ is a secondary pollutant generated by reactions between $\mathrm{NO}_{\mathrm{x}}$, Volatile Organic Compounds and solar radiation (Jacob 1999), and as the diurnal cycle of temperature follows solar cycle, we would expect statistical interactions between $\mathrm{O}_{3}$ and temperature. To identify associations between mobility and COVID-19, by controlling confounding factors, we used the general equation 1 . We performed a detailed sensitivity analyses between the variables, shown supplementary material S1 expanding the equation 1 into 18 configurations.

$$
\log \left(u_{i}\right)=\beta_{0}+\beta_{1} * R M I_{m, n}+s\left(P M_{2.5_{m}}\right)+s\left(O_{3_{m}}\right)+s\left(R H_{m}\right)+s\left(t e m p_{m}\right)+s(\text { time })+s(\text { dow })
$$

Where $\log (\mathrm{u})$ is the $\log$-transform of the daily cases and deaths of COVID-19 with a quasi-poisson or negative binomial distribution $i, \beta_{0}$ is the intercept $\beta_{1}$ is the coefficient that represents the association of $R M I_{m, n}$ moving average $\mathrm{m}$ using mobility data $\mathrm{n}$ from Google or SIMI-SP on cases, $s$ the thin plate, and temp temperature, RH relative humidity, $\mathrm{PM}_{2.5}$ and $\mathrm{O}_{3}$ atmospheric pollutants, time represents each day to account unobserved factors, $\mathrm{s}(\mathrm{dow})$ is the cubic spline function with dimension of 7 to account for each day of the week. We used thin-plate splines to avoid knot placement and, therefore, avoid overfitting (Wood 2003). The predicted number of COVID-19 cases is then $\exp \left(\beta_{0}+\beta_{1} * R M I_{l}\right)$, which is conditionally to the other predictors. Although more pollutants are reported by São Paulo (QUALAR) air quality stations, e.g., $\mathrm{NO}_{2}, \mathrm{CO}$, and $\mathrm{PM}_{10}$, we limited the model to $\mathrm{PM}_{2.5}$ and $\mathrm{O}_{3}$ to avoid multicollinearity between $\mathrm{PM}_{2.5}$ and these other species. As the objective of this study estimate the associations 
medRxiv preprint doi: https://doi.org/10.1101/2021.02.08.21250113; this version posted August 3, 2021. The copyright holder for this preprint (which was not certified by peer review) is the author/funder, who has granted medRxiv a license to display the preprint in perpetuity.

It is made available under a CC-BY 4.0 International license .

between daily residential mobility index (RMI), air pollution, and meteorology, and daily cases and deaths for COVID19 in São Paulo, Brazil, the data were filtered starting on March $24^{\text {th }}$, 2020. In order to apply GAM, we used the R programming language and the library mgcv (v1.8.31) (R Core Team 2021; Wood 2017). One limitation of our method is the limited sample, consisting of 292 days between March 27, 2020 and December $12^{\text {nd }}, 2020$. Nevertheless, we performed a comprehensive sensitivity analysis, as we evaluated 18 equations with 4-21 moving average lag periods, and compared RMI data from Google and SIMI-SP with quasi-poisson and negative binomial distributions, this resulted in 1296 regressions. To ensure consistency, we repeated the analyses with data only until November 2020 finding similar results.

\subsection{Association between air pollution and COVID-19}

We also investigated the effects of air pollution on COVID-19. In this case, we are interested in evaluating the effect of specific level of air pollution present on the same or previous specific days, rather than the moving average of air pollution. The use of lag models is recommended to identify associations with air pollution and health outcomes (Gasparrini 2011; Peng and Dominici 2008). Then, we used lags to account for the delayed effect of air pollution on COVID-19 with a quasi-poisson and negative binomial distributions (Wood 2017; Zeileis et al. 2008). We used singlelag generalized additive models and different configuration for confounding variables with thin plate splines. To identify associations between air pollution and COVID-19, by controlling confounding factors, we used the general equation 2. A sensitivity analyses is available on supplementary material S2, expanding the equation 2 into 8 configurations.

$$
\log \left(u_{i}\right)=\beta_{0}+\beta_{1} * P_{L}+s\left(R M I_{L}\right)+s\left(\text { temp }_{L}\right)+s(\text { time })+s(\text { dow })
$$

Where $\mathrm{P}$ represents the air pollutant concentrations of $P M_{2.5_{L}}$ or $O_{3_{L}}, t e m p_{L}, R H_{L}$, and $R M I_{L}$ are the delayed environmental quantities at different lags 1 . The methodology is similar as we presented to calculate the effect of the RMI index, but in this case, we controlled all the variables except air pollution. This is useful to compare with other studies and to see the importance of exposure to air pollution and its effects on COVID-19 cases. Then, we calculated the relative risks of new cases by the increment of $10 \mu \mathrm{g} \cdot \mathrm{m}^{-3}$ air pollution with the expression ex $\mathrm{p}\left(\beta_{1} * p\right.$ ollutant $)$.

\section{Results}

\subsection{Mobility and COVID-19 cases and deaths}


medRxiv preprint doi: https://doi.org/10.1101/2021.02.08.21250113; this version posted August 3, 2021. The copyright holder for this preprint (which was not certified by peer review) is the author/funder, who has granted medRxiv a license to display the preprint in perpetuity.

It is made available under a CC-BY 4.0 International license .

The associations between mobility indices RMI SIMI-SP and Google, parameter $\beta_{1}$ on equation 1, are shown on Figure 4. The x-axis represents the model configurations from equations 1-20 and the facet labels 4-21 the delayed effect of exposure as moving average. RMI Google was not significantly associated with COVID-19 in any model. This can be explained by the low correlation between RMI Google with Cases -0.19 and with Deaths 0.1 (not significant), as shown on Table 1 on supplementary material. On the contrary, we did find statistical association between RMI SIMISP and COVID-19. It is evident increasing the mobility, that is staying out-of-home which results in lower RMI, have a delayed effect increasing COVID-19 cases after four to nine days of exposure. It has been reported that the incubation period for COVID-19 is between 4.5- 6.4 days (Kraemer et al. 2020; Lai et al. 2020; Lauer et al. 2020). We believe that the appearance of cases after more days of exposure than the number reported in other studies, is due to the fact that the Reverse transcription polymerase chain reaction (RT-PCR) tests to detect virus takes between 3 days and one week. This explanation also applies to the expected cases after seven, eight, nine and 18 days of exposure. Regarding the deaths, we found associations after 18-21 days of exposure, which makes sense because more time is needed between exposure, severe disease and death outcome. We also found increased deaths after 4 days of exposure, but the magnitude is also lower, near to zero. Furthermore, there is a trend after 14 days of exposure decreasing the $\beta_{1}$, in which most of models signalized the association with mobility and COVID-19 death. These associations were found with negative binomial and quasi-poisson regressions, and the reader can reproduce these results following the instructions available in this public repository https://gitlab.com/ibarraespinosa/covid191.

After analyzing the coefficients of association RMI and COVID-19, we calculated the expected outcomes with different moving average periods. Then, we grouped the results to obtain one curve exposure-response for cases and deaths, as shown on Figure 5. They grey points represents the expected cases and deaths under different exposure levels, expressed as RMI SIMI-SP and the red curves a smooth LOESS regression with 95\% confidence interval for all associations. Our results shows that when people stayed home, COVID-19 cases and deaths decrease. Likewise, with less RMI or increased outdoor activities, there more cases and deaths for COVID-19. The mean RMI SIMI-SP during pre-quarantine (before March 15) was $31.10 \%$ and just after the quarantine (between March $27^{\text {th }}$ and April $15^{\text {th }}$, 2020) was $54.77 \%$, increasing the isolation. Then, the association between RMI and cases was assessed with the median RMI SIMI-SP of $45.28 \%$ post-quarantine, presented as the second vertical black line in Figure 5. Under this RMI we would expect 1,212 cases (95\% CI: 1,189 to 1,235 ) and 44 deaths (95\% CI: 40 to 47). We applied the expected outcomes for several RMI values to evaluate the resulting cases for RMI extremes. For example, under the first 
medRxiv preprint doi: https://doi.org/10.1101/2021.02.08.21250113; this version posted August 3, 2021. The copyright holder for this preprint (which was not certified by peer review) is the author/funder, who has granted medRxiv a license to display the preprint in perpetuity.

It is made available under a CC-BY 4.0 International license .

quantile of RMI SIMI-SP, first vertical black line, that is $41.38 \%$, it would result in 1,757 cases (95\% CI: 1,734 to 1,780 ) and 80 deaths (95\% CI: 77 to 84 ) and under the third quantile of $48.87 \%$, third vertical black line, it would result in 846 cases (95\% CI: 823 to 869) and 25 deaths (95\% CI: 22 to 29). Analyzing the extreme values shows that, if the RMI SIMI-SP were 37.82\% would result in 2,311 cases (95\% CI: 2,285 to 2,338) and 127 deaths (95\% CI: 122 to 131 ) and with RMI SIMI-SP of 59.25\%, 351 cases (95\% CI: 325 to 378 ) and 8 deaths (95\% CI: 4 to 13). We added a repeated histogram of RMI SIMI-SP on the top of Figure 5, with the RMI quantiles. Therefore, avoiding unnecessary outdoor activities and staying at home would result in a reduction in expected cases and deaths.

\subsection{Air pollution and COVID-19 cases}

We assessed the association between COVID-19 and increment of $10 \mu \mathrm{g} \cdot \mathrm{m}^{-3}$ of $\mathrm{PM}_{2.5}$ and $\mathrm{O}_{3}$. Figure 6 shows the relative risks of COVID-19 cases and deaths after 1-21 days of exposure. We found that $\mathrm{PM}_{2.5}$ and $\mathrm{O}_{3}$ have positive relative risks for cases and deaths with both distributions. Specifically, $\mathrm{O}_{3}$ increments cases after four and 13 days of exposure, and deaths after two, four, 19 and 20 days of exposure, and $\mathrm{PM}_{2.5}$ poses positive relative risks after two, 10 and 13 days of exposure for cases and 17 days of exposure for deaths. Nevertheless, there are some relative risks below 1, which would provide protective factors for $\mathrm{O}_{3}$ and $\mathrm{PM}_{2.5}$ after 17 days for cases where more research is needed. The order of magnitude of relative risks within lagged group is very similar with different models. Therefore, we averaged the relative risks within groups resulting that an increment of $10 \mu \mathrm{g} \cdot \mathrm{m}^{-3} \mathrm{of} \mathrm{O}_{3}$ produce cases-relative risks of 1.066 (95\% CI: 1.005 to 1.131 ) and 1.084 (95\% CI: 1.007 to 1.168$)$ after four and 13 days of exposure, respectively. In the case of deaths, the $\mathrm{O}_{3}$-related relative risks are 1.067 (95\% CI: 1.008 to 1.129$), 1.050$ (95\% CI: 1.003 to 1.100 ), 1.070 (95\% CI: 1.012 to 1.131 ) and 1.066 (95\% CI: 1.001 to 1.135$)$ after two, four, 19 and 20 days of exposure, respectively. Likewise, an increment of $10 \mu \mathrm{g} \cdot \mathrm{m}^{-3}$ of $\mathrm{PM}_{2.5}$ produce cases-relative risks 1.151 (95\% CI: 1.048 to 1.264 ), 1.113 (95\% CI: 1.002 to 1.236$)$ and $1.157(95 \%$ CI: 1.012 to 1.323$)$ after three, 10 and 14 days of exposure and the risk for death is 1.086 (95\% CI: 1.008 to 1.170$)$ after 17 days. Based on these results, air pollution significantly increases COVID-19 cases and deaths. The mean relative risks for cases are 1.140 for $\mathrm{PM}_{2.5}$ and 1.075 for $\mathrm{O}_{3}$, meaning that $\mathrm{PM}_{2.5}$ increments 1.06 times more COVID-19 cases than $\mathrm{O}_{3}$. In the case of deaths, the relative risk for $\mathrm{O}_{3}$ is 1.063 and for $\mathrm{PM}_{2.5} 1.086$.

\section{Discussion}


medRxiv preprint doi: https://doi.org/10.1101/2021.02.08.21250113; this version posted August 3, 2021. The copyright holder for this preprint (which was not certified by peer review) is the author/funder, who has granted medRxiv a license to display the preprint in perpetuity.

It is made available under a CC-BY 4.0 International license .

In this study, we used a semiparametric Generalized Additive Model (GAM) to explore possible associations between RMI, air pollutants, and COVID-19 cases and deaths in São Paulo, Brazil, for March 27 $7^{\text {th }}, 2020$ through December $30^{\text {th }}$, 2020. We controlled environmental factors such as air temperature, relative humidity, and air pollutant concentrations $\left(\mathrm{PM}_{2.5}\right.$ and $\left.\mathrm{O}_{3}\right)$ with thin splines. Arguably, models like the one used here are more commonly applied to much larger datasets. However, we present findings and caveats, to provide early evidence on the transmission of COVID-19, and as part of efforts to highlight the potential value of the recently developed mobility indices.

We found statistical associations between RMI and COVID-19 cases and a lower RMI (i.e., the increase of residents staying-at-home) increase COVID-19 cases. Likewise, increased isolation decreases COVID-19 cases. The median RMI after quarantine started was $45.28 \%$, which represents most of the period of study. Under this RMI, we would expect 1,212 cases (95\% CI: 1,189 to 1,235) and 44 deaths (95\% CI: 40 to 47). São Paulo's COVID-19 median values are 1,214 and 46 for cases and deaths, which means that our predictions align with our observations and previous literature regarding COVID-19 cases (Martins et al. 2020). We analyzed RMI values to provide policymakers with several options to mitigate the number of COVID-19 cases and deaths and support public health system. Then, if the isolation is increased with the RMI SIMI-SP index from $45.28 \%$ to $50.00 \%$, we would expect 774 (95\% CI: 751 to 797) cases and 23 (95\% CI: 19 to 26) deaths, representing a reduction 438 cases and 21 deaths, a third of the cases and half of the deaths. Therefore, a policymaker can use this information and define RMI targets based on the capacity of their health system.

We evaluated the effect of moving average air pollution on COVID-19 cases and deaths and we found strong associations. The average of the significant relative risk over the 21 days of delayed exposure is 1.140 (95\% CI: 1.021 to 1.274 ) for cases and 1.086 (95\% CI: 1.008 to 1.170 ) for deaths due to an increment of $10 \mu \mathrm{g} \cdot \mathrm{m}^{-3} \mathrm{of} \mathrm{PM}_{2.5}$, and 1.075 ( $95 \%$ CI: 1.006 to 1.150 ) for cases and 1.086 (95\% CI: 1.008 to 1.170 ) for deaths due to an increment of $10 \mu \mathrm{g} \cdot \mathrm{m}^{-3} \mathrm{of}$ $\mathrm{O}_{3}$. A global study about the association between air pollution and death-risk for COVID-19 found that in South America the attributable fraction (AF) of COVID-19 mortality due $\mathrm{PM}_{2.5}$, calculated as 1-1/RR, is approximately $15 \%$ in São Paulo (Pozzer et al. 2020), while the AF due the increment of $\mathrm{PM}_{2.5}$ in Sao Paulo is 12.28. Another study in China showed that $10 \mu \mathrm{g} \cdot \mathrm{m}^{-3}$ of $\mathrm{O}_{3}$ results in relative risk of 1.047 (Zhu et al. 2020a), which is slightly lower than our results of 1.075 presented in this study. Zhang et al (2021) found a country-average relative risk for $\mathrm{PM}_{2.5}$ of 1.06 (95\% CI: 1.03 to 1.08), while relative risk found in Northeast and Southwest China oscillate around 1.2, similar to our result 1.140 and another Chinese study found a relative risk of relative risk of 1.18 for $\mathrm{PM}_{2.5}$ (Zhu et al. 2020b). 
medRxiv preprint doi: https://doi.org/10.1101/2021.02.08.21250113; this version posted August 3, 2021. The copyright holder for this preprint (which was not certified by peer review) is the author/funder, who has granted medRxiv a license to display the preprint in perpetuity.

It is made available under a CC-BY 4.0 International license .

As this study is based on 292 days of data, future research should consider the potential effects of a more extended period to study the effect of air pollution on COVID-19 related cases and deaths. Recent social distancing and quarantines have been introduced on unprecedented scales, made necessary by the high transmissivity and severity of COVID-19, and the lack of effective vaccines or testing programs (Cohen and Kupferschmidt 2020). This strongly suggests that mobility indices can be used to study infectious disease transmission and assess the effectiveness of large-scale isolation and quarantine style management activities. Therefore, policymakers can use the new mobility dataset to enforce efforts to implement more effective social distancing and quarantine-based management strategies for COVID-19 in the other states of Brazil.

The use of mask could expand these types of studies, to answer the question if increased mobility using appropriate masks would increases COVID-19. Unfortunately, to the best of our knowledge, there are no time-series available about use of mask in Brazil. Also, the first vaccine applied in Brazil was on January 17, then our study did not include the effects of vaccination (SP 2021). Then, future studies which seek to study the effect of exposure using mobility indices on COVID-19 would need to control newer variables such as, use of mask and number of COVID-19 vaccines applied.

\section{Conclusion}

Spatial distancing was proven to be a determining factor to control COVID-19 cases and deaths. RMI is also significantly associated with COVID-19 cases and deaths. Increased isolation decreases COVID-19 cases while increased mobility is related to a higher number of COVID-19 cases and deaths. Our predictions align with mean observations of COVID-19 cases. Air pollutant models revealed that an increment of $10 \mu \mathrm{g} \cdot \mathrm{m}^{-3} \mathrm{of} \mathrm{PM}_{2.5}$ and $\mathrm{O}_{3}$ produces a relative risk of 1.140 (95\% CI: 1.021 to 1.274$)$ for cases and of 1.086 (95\% CI: 1.008 to 1.170 ), and 1.075 (95\% CI: 1.006 to 1.150 ) for cases and 1.063 (95\% CI: 1.006 to 1.124$)$ for deaths, respectively. 
medRxiv preprint doi: https://doi.org/10.1101/2021.02.08.21250113; this version posted August 3, 2021. The copyright holder for this preprint (which was not certified by peer review) is the author/funder, who has granted medRxiv a license to display the preprint in perpetuity.

It is made available under a CC-BY 4.0 International license .

\section{References}

Abrutzky R, Ibarra S, Matus P, Romero-Lankao P, Pereyra V, Dawidowski L. 2013. Atmospheric pollution and mortality. A comparative study between two Latin American cities: Buenos Aires (Argentina) and Santiago (Chile). Int J Environ Heal 6; doi:10.1504/IJENVH.2013.056977.

Alves THE, de Souza TA, de Almeida Silva S, Ramos NA, de Oliveira SV. 2020. Underreporting of death by COVID19 in Brazil's second most populous state. medRxiv.

Badr HS, Du H, Marshall M, Dong E, Squire MM, Gardner LM. 2020. Association between mobility patterns and COVID-19 transmission in the USA: a mathematical modelling study. Lancet Infect Dis 20: 1247-1254.

Bolaño-Ortiz TR, Camargo-Caicedo Y, Puliafito SE, Ruggeri MF, Bolaño-Diaz S, Pascual-Flores R, et al. 2020. Spread of SARS-CoV-2 through Latin America and the Caribbean region: a look from its economic conditions, climate and air pollution indicators. Environ Res 109938; doi:https://doi.org/10.1016/j.envres.2020.109938.

Buss LF, Prete CA, Abrahim CMM, Mendrone A, Salomon T, de Almeida-Neto C, et al. 2020. Three-quarters attack rate of SARS-CoV-2 in the Brazilian Amazon during a largely unmitigated epidemic. Science (80- ); doi:10.1126/science.abe9728.

Carracedo-Martl'linez E, Taracido M, Tobias A, Saez M, Figueiras A. 2010. Case-crossover analysis of air pollution health effects: a systematic review of methodology and application. Environ Health Perspect 118: 1173-1182.

CETESB. 2021. Sistema de monitoreamento de qualidade do ar QUALAR. Available: https://qualar.cetesb.sp.gov.br/ [accessed 4 January 2021].

Cohen J, Kupferschmidt K. 2020. Countries test tactics in 'war'against COVID-19.

Dantas G, Siciliano B, França BB, da Silva CM, Arbilla G. 2020. The impact of COVID-19 partial lockdown on the air quality of the city of Rio de Janeiro, Brazil. Sci Total Environ 729:139085; doi:https://doi.org/10.1016/j.scitotenv.2020.139085.

Debone D, da Costa M V, Miraglia SGEK. 2020. 90 days of COVID-19 social distancing and its impacts on air quality and health in Sao Paulo, Brazil. Sustainability 12: 7440.

Dominici F, McDermott A, Hastie TJ. 2004. Improved semiparametric time series models of air pollution and 
medRxiv preprint doi: https://doi.org/10.1101/2021.02.08.21250113; this version posted August 3, 2021. The copyright holder for this preprint (which was not certified by peer review) is the author/funder, who has granted medRxiv a license to display the preprint in perpetuity.

It is made available under a CC-BY 4.0 International license .

mortality. J Am Stat Assoc 99: 938-948.

Dong E, Du H, Gardner L. 2020. An interactive web-based dashboard to track COVID-19 in real time. Lancet Infect Dis 20: $533-534$.

Dutheil F, Baker JS, Navel V. 2020. COVID-19 as a factor influencing air pollution? Environ Pollut (Barking, Essex 1987).

Freitas ED, Rozoff CM, Cotton WR, Dias PLS. 2007. Interactions of an urban heat island and sea-breeze circulations during winter over the metropolitan area of São Paulo, Brazil. Boundary-Layer Meteorol 122: 43-65.

Freitas, Ibarra-Espinosa S, Gavidia-Calderón M, Rehbein A, Abou Rafeem Sameh Martins J, Martins L, et al. 2020. Mobility restrictions and air quality under COVID-19 pandemic in São Paulo, Brazil. Preprints; doi:10.20944/preprints202004.0515.v1.

G1. 2020. Governo obedece à ordem do STF, e Ministério da Saúde volta a divulgar dados completos da covid | Política $\mid \mathrm{G} 1$.

Gasparrini A. 2011. Distributed lag linear and non-linear models in $\{R\}$ : the package $\{\mathrm{dlnm}\}$. J Stat Softw 43: 1-20.

Gatalo O, Tseng K, Hamilton A, Lin G, Klein E. 2020. Associations between phone mobility data and COVID-19 cases. Lancet Infect Dis.

GESP. 2020. Decreta quarentena no Estado de São Paulo, no contexto da pandemia do CO VID-19. Available: http://dobuscadireta.imprensaoficial.com.br/default.aspx ?DataPublicacao=20200323\&Caderno=DOEI\&NumeroPagina $=1$.

Google. 2021. Community Mobility Reports. Available: https://www.google.com/covid19/mobility/ [accessed 4 January 2021].

Gupta R, Collier D, De Marco A, Ferreira I, Meng B, Datir R, et al. 2021. SARS-CoV-2 B. 1.1. 7 escape from mRNA vaccine-elicited neutralizing antibodies. Prepr (Version 1) available Res Sq [https//doi.org/1021203/rs3.rs$156101 / \mathrm{v} 1]$.

Hastie TJ, Tibshirani RJ. 1990. Generalized additive models. CRC press.

IBGE. 2020. Instituto Brasileiro de Geografia e Estatística -- Estimativas da População. Available: 
medRxiv preprint doi: https://doi.org/10.1101/2021.02.08.21250113; this version posted August 3, 2021. The copyright holder for this preprint (which was not certified by peer review) is the author/funder, who has granted medRxiv a license to display the preprint in perpetuity.

It is made available under a CC-BY 4.0 International license .

https://ftp.ibge.gov.br/Estimativas_de_Populacao/Estimativas_2020/estimativa_dou_2020.pdf [accessed 29 July 2021].

Jacob DJ. 1999. Introduction to atmospheric chemistry. Princeton University Press.

Kleiber C, Zeileis A. 2008. Applied econometrics with R. Springer Science \& Business Media.

Kraemer MUG, Yang C-H, Gutierrez B, Wu C-H, Klein B, Pigott DM, et al. 2020. The effect of human mobility and control measures on the COVID-19 epidemic in China. Science (80- ) 368: 493-497.

Kupferschmidt K. 2021. Fast-spreading U.K. virus variant raises alarms. Science (80- ) 371:9-10; doi:10.1126/science.371.6524.9.

Lai C-C, Shih T-P, Ko W-C, Tang H-J, Hsueh P-R. 2020. Severe acute respiratory syndrome coronavirus 2 (SARSCoV-2) and corona virus disease-2019 (COVID-19): the epidemic and the challenges. Int J Antimicrob Agents 105924.

Lauer SA, Grantz KH, Bi Q, Jones FK, Zheng Q, Meredith HR, et al. 2020. The incubation period of coronavirus disease 2019 (COVID-19) from publicly reported confirmed cases: estimation and application. Ann Intern Med.

Leitte AM, Petrescu C, Franck U, Richter M, Suciu O, Ionovici R, et al. 2009. Respiratory health, effects of ambient air pollution and its modification by air humidity in Drobeta-Turnu Severin, Romania. Sci Total Environ 407: 4004-4011.

Martins LD, da Silva I, Batista WV, de Fátima Andrade M, de Freitas ED, Martins JA. 2020. How socio-economic and atmospheric variables impact COVID-19 and influenza outbreaks in tropical and subtropical regions of Brazil. Environ Res 191: 110184.

Morawska L, Milton DK. 2020. It Is Time to Address Airborne Transmission of Coronavirus Disease 2019 (COVID19). Clin Infect Dis; doi:10.1093/cid/ciaa939.

Morris DH, Yinda KC, Gamble A, Rossine FW, Huang Q, Bushmaker T, et al. 2020. Mechanistic theory predicts the effects of temperature and humidity on inactivation of SARS-CoV-2 and other enveloped viruses. bioRxiv; doi:10.1101/2020.10.16.341883.

Nakada LYK, Urban RC. 2020. COVID-19 pandemic: Impacts on the air quality during the partial lockdown in São 
medRxiv preprint doi: https://doi.org/10.1101/2021.02.08.21250113; this version posted August 3, 2021. The copyright holder for this preprint (which was not certified by peer review) is the author/funder, who has granted medRxiv a license to display the preprint in perpetuity.

It is made available under a CC-BY 4.0 International license .

Paulo state, Brazil. Sci Total Environ 730:139087; doi:https://doi.org/10.1016/j.scitotenv.2020.139087.

Peng RD, Dominici F. 2008. Statistical methods for environmental epidemiology with R. R a case study air Pollut Heal.

Pozzer A, Dominici F, Haines A, Witt C, Münzel T, Lelieveld J. 2020. Regional and global contributions of air pollution to risk of death from COVID-19. Cardiovasc Res; doi:10.1093/cvr/cvaa288.

R Core Team. 2021. R: A Language and Environment for Statistical Computing.

Rehbein A, Dutra LMM, Ambrizzi T, da Rocha RP, Reboita MS, da Silva GAM, et al. 2018. Severe weather events over southeastern Brazil during the 2016 dry season. Adv Meteorol 2018.

Saúde M de. 2021. Coronavírus Brasil. Available: https://covid.saude.gov.br/ [accessed 4 January 2021].

SP. 2021. Nurse Monica Calazans is the first vaccinated person in the country. Available: https://www.saopaulo.sp.gov.br/noticias-coronavirus/nurse-monica-calazans-is-the-first-vaccinated-person-inthe-country/.

Tello-Leal E, Macías-Hernández BA. 2020. Association of environmental and meteorological factors on the spread of COVID-19 in Victoria, Mexico, and air quality during the lockdown. Environ Res 110442; doi:https://doi.org/10.1016/j.envres.2020.110442.

Tian H, Liu Y, Li Y, Wu C-H, Chen B, Kraemer MUG, et al. 2020. An investigation of transmission control measures during the first 50 days of the COVID-19 epidemic in China. Science (80- ) 368:638-642; doi:10.1126/science.abb6105.

Tosepu R, Gunawan J, Effendy DS, Lestari H, Bahar H, Asfian P, et al. 2020. Correlation between weather and Covid19 pandemic in Jakarta, Indonesia. Sci Total Environ 138436.

Vera C, Higgins W, Amador J, Ambrizzi T, Garreaud R, Gochis D, et al. 2006. Toward a Unified View of the American Monsoon Systems. J Clim 19:4977-5000; doi:10.1175/JCLI3896.1.

Wang J, Tang K, Feng K, Lv W. 2020a. High temperature and high humidity reduce the transmission of COVID-19. Available SSRN 3551767.

Wang M, Jiang A, Gong L, Luo L, Guo W, Li C, et al. 2020b. Temperature significant change COVID-19 
medRxiv preprint doi: https://doi.org/10.1101/2021.02.08.21250113; this version posted August 3, 2021. The copyright holder for this preprint (which was not certified by peer review) is the author/funder, who has granted medRxiv a license to display the preprint in perpetuity.

It is made available under a CC-BY 4.0 International license .

Transmission in 429 cities. medRxiv.

Wickham H. 2016. ggplot2: Elegant Graphics for Data Analysis. Springer-Verlag New York.

Wood S. 2017. Generalized Additive Models: An Introduction with R. Chapman and Hall/CRC.

Wood SN. 2003. Thin plate regression splines. J R Stat Soc Ser B (Statistical Methodol 65: 95-114.

Wu X, Nethery RC, Sabath BM, Braun D, Dominici F. 2020. Exposure to air pollution and COVID-19 mortality in the United States. medRxiv.

Zeileis A, Kleiber C, Jackman S. 2008. Regression Models for Count Data in R. J Stat Software, Artic 27:1-25; doi:10.18637/jss.v027.i08.

Zhang X, Tang M, Guo F, Wei F, Yu Z, Gao K, et al. 2021. Associations between air pollution and COVID-19 epidemic during quarantine period in China. Environ Pollut 268:115897; doi:https://doi.org/10.1016/j.envpol.2020.115897.

Zhu Y, Xie J, Huang F, Cao L. 2020a. Association between short-term exposure to air pollution and COVID-19 $\begin{array}{llllll}\text { infection: } & \text { Evidence } & \text { from } & \text { China. } & \text { Sci } & \text { Total }\end{array}$ doi:https://doi.org/10.1016/j.scitotenv.2020.138704.

Zhu Y, Xie J, Huang F, Cao L. 2020b. The mediating effect of air quality on the association between human mobility and COVID-19 infection in China. Environ Res 189:109911; doi:https://doi.org/10.1016/j.envres.2020.109911.

Acknowledgments: The authors would like to thank the São Paulo's Environmental Agency (CETESB), for making possible the use of air quality measurements through its QUALAR platform. The authors would like to thank Lena Goodwin for the support. Funding: E.D.F. efforts were supported by São Paulo Research Foundation (FAPESP) Grants No. 2015/03804-9 and 2016/18438-0; A.R. efforts were also supported by FAPESP Grant No. 2016/10557-0. Authors also thank "Coordenação de Aperfeiçoamento de Pessoal de Nível Superior - Brasil" (CAPES) Finance Code 001; Author contributions: Conceptualization, S.I.E. and E.F.; Methodology, S.I.E, E,F., F.D., K.R., A.R.; Investigation, S.I.E, E.F., K.R., F.D. and A.R.; Writing - Original Draft, S.I.E., K.R. and E.D.; Writing - Review \& Editing, S.I.E., K.R., E.F., F.D. and A.R.; Funding Acquisition, E.F.; Supervision, E.F. and F.D; Competing interests: 
medRxiv preprint doi: https://doi.org/10.1101/2021.02.08.21250113; this version posted August 3, 2021. The copyright holder for this preprint (which was not certified by peer review) is the author/funder, who has granted medRxiv a license to display the preprint in perpetuity.

It is made available under a CC-BY 4.0 International license.

Authors declare no competing interests; and Data and materials availability: All the data and code used in this study is available at the only repository https://gitlab.com/ibarraespinosa/covid191. 
medRxiv preprint doi: https://doi.org/10.1101/2021.02.08.21250113; this version posted August 3, 2021. The copyright holder for this preprint (which was not certified by peer review) is the author/funder, who has granted medRxiv a license to display the preprint in perpetuity.

It is made available under a CC-BY 4.0 International license .

\section{Figure captions}
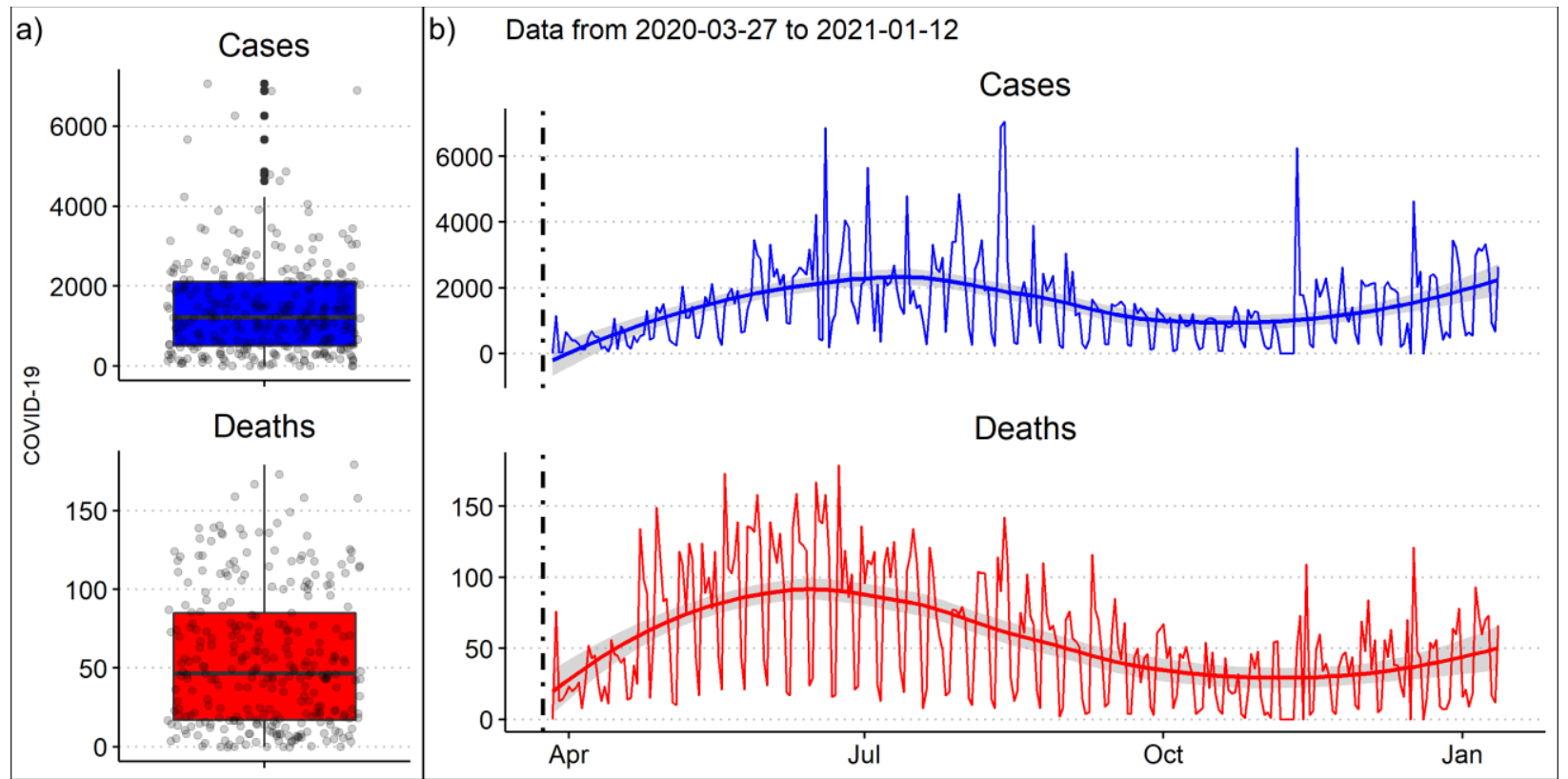

Figure 1. Daily cases and deaths of COVID-19 in (a) boxplots and (b) time series in São Paulo, Brazil, between March $27^{\text {th }}, 2020$ and January $12^{\text {nd }}, 2021$ (Saúde 2021). The smooth lines on panel b) are the LOESS regression made with ggplot2 and R (R Core Team 2021; Wickham 2016). 
medRxiv preprint doi: https://doi.org/10.1101/2021.02.08.21250113; this version posted August 3, 2021. The copyright holder for this preprint (which was not certified by peer review) is the author/funder, who has granted medRxiv a license to display the preprint in perpetuity.

It is made available under a CC-BY 4.0 International license .

a)

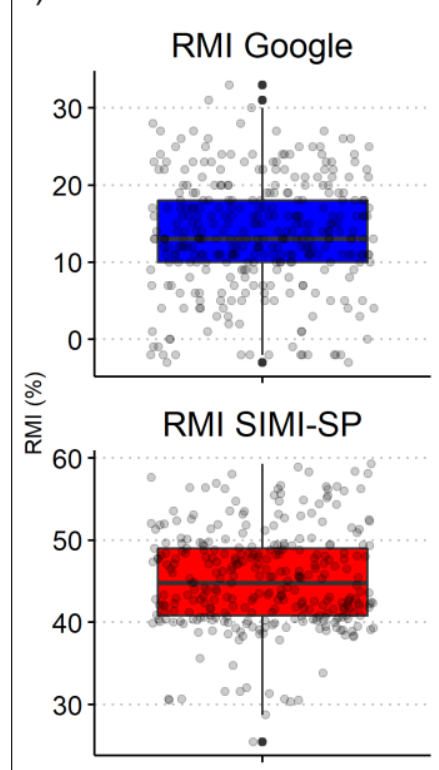

b) RMI Google: 2020-02-15 to 2021-01-08. RMI SIMI-SP: 2020-02-26 to 2021-01-03

RMI Google

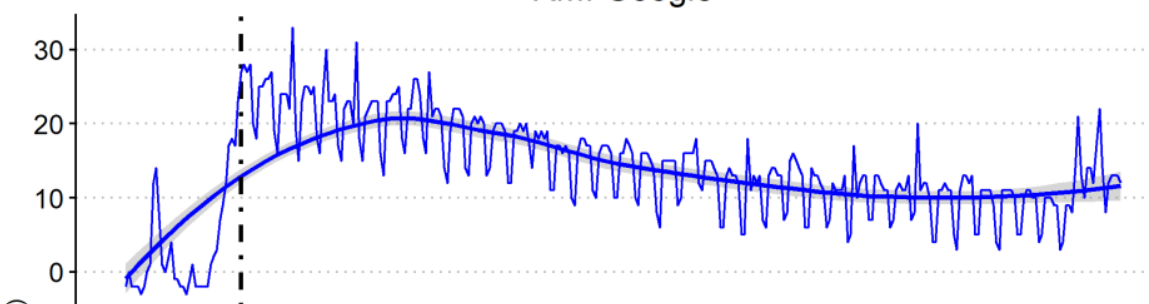

RMI SIMI-SP

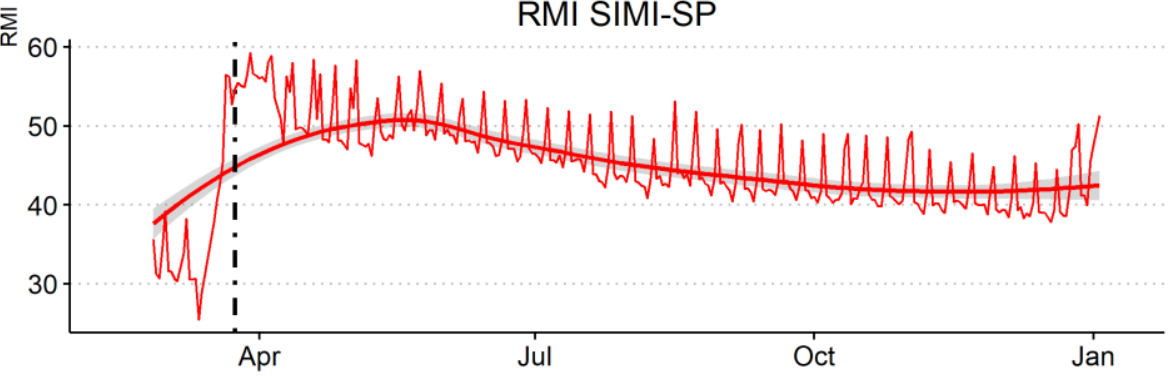

Figure 2. RMI values in São Paulo, Brazil, in a) boxplots and b) times series between January $15^{\text {th }}$ and December $2^{\text {th }}, 2020$ for RMI Google (Google 2021) and between February 26, 2020 and January 3, 2021. Black vertical line shows when started the quarantine in São Paulo on March, 24. The smooth lines on panel b) are the LOESS regression made with ggplot2 and R (R Core Team 2021; Wickham 2016). 


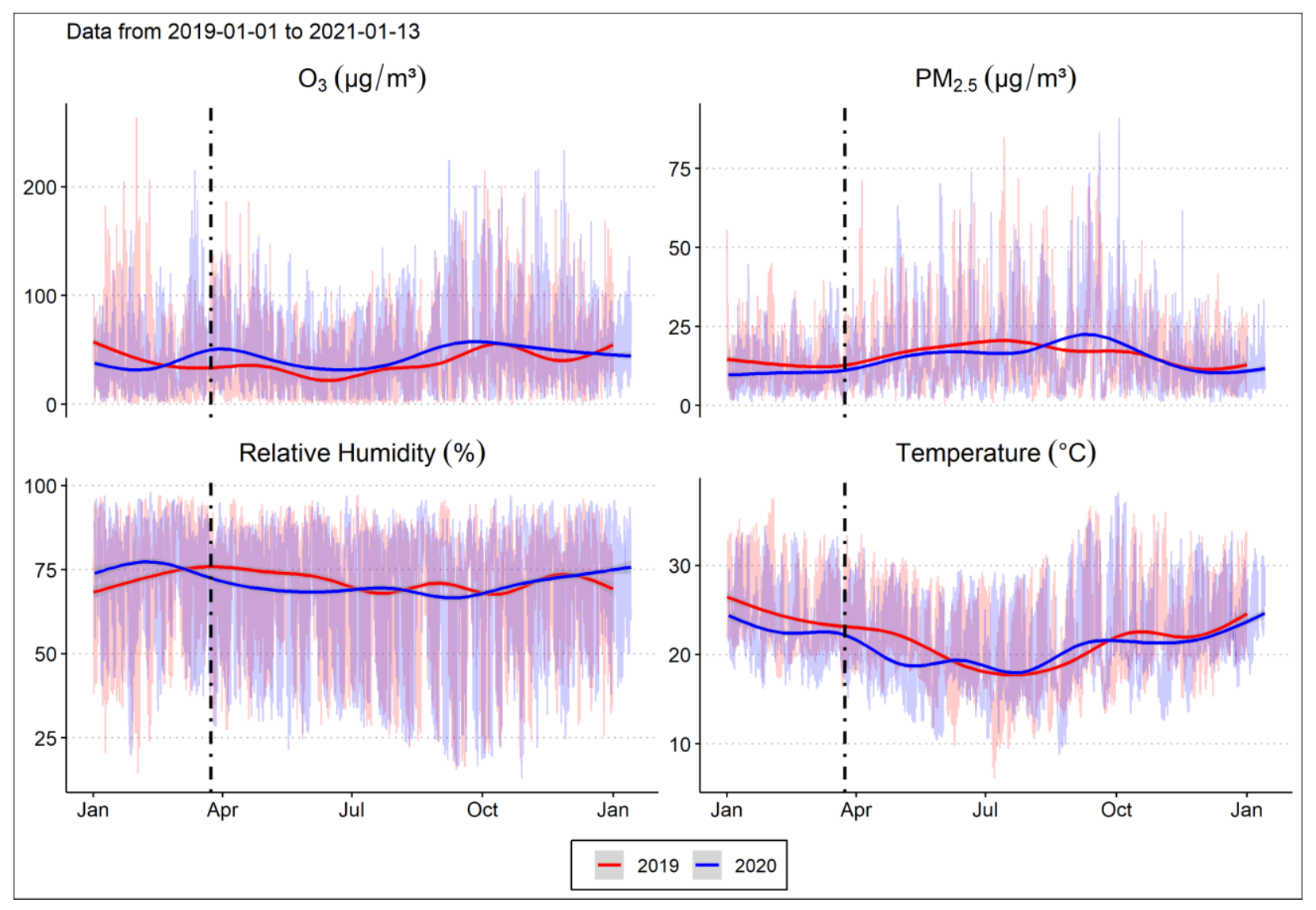

Figure 3. Hourly means of $\mathrm{O}_{3}\left(\mu \mathrm{g} / \mathrm{m}^{3}\right), \mathrm{PM}_{2.5}\left(\mu \mathrm{g} / \mathrm{m}^{3}\right)$ and Air Temperature $\left({ }^{\circ} \mathrm{C}\right)$ between January $1^{\text {st }} 2020$ and January $4^{\text {th }}, 2021$ for the city of São Paulo, Brazil (CETESB 2021). The means considered the parameters from the stations Congonhas, Cid.Universitária-USP-Ipen, Santana, Ibirapuera, Mooca, Pinheiros and Parque D. Pedro II. The red and blue lines are the automatic LOESS regression made with ggplot2 and R (R Core Team 2021; Wickham 2016). 
medRxiv preprint doi: https://doi.org/10.1101/2021.02.08.21250113; this version posted August 3, 2021. The copyright holder for this preprint (which was not certified by peer review) is the author/funder, who has granted medRxiv a license to display the preprint in perpetuity.

It is made available under a CC-BY 4.0 International license .

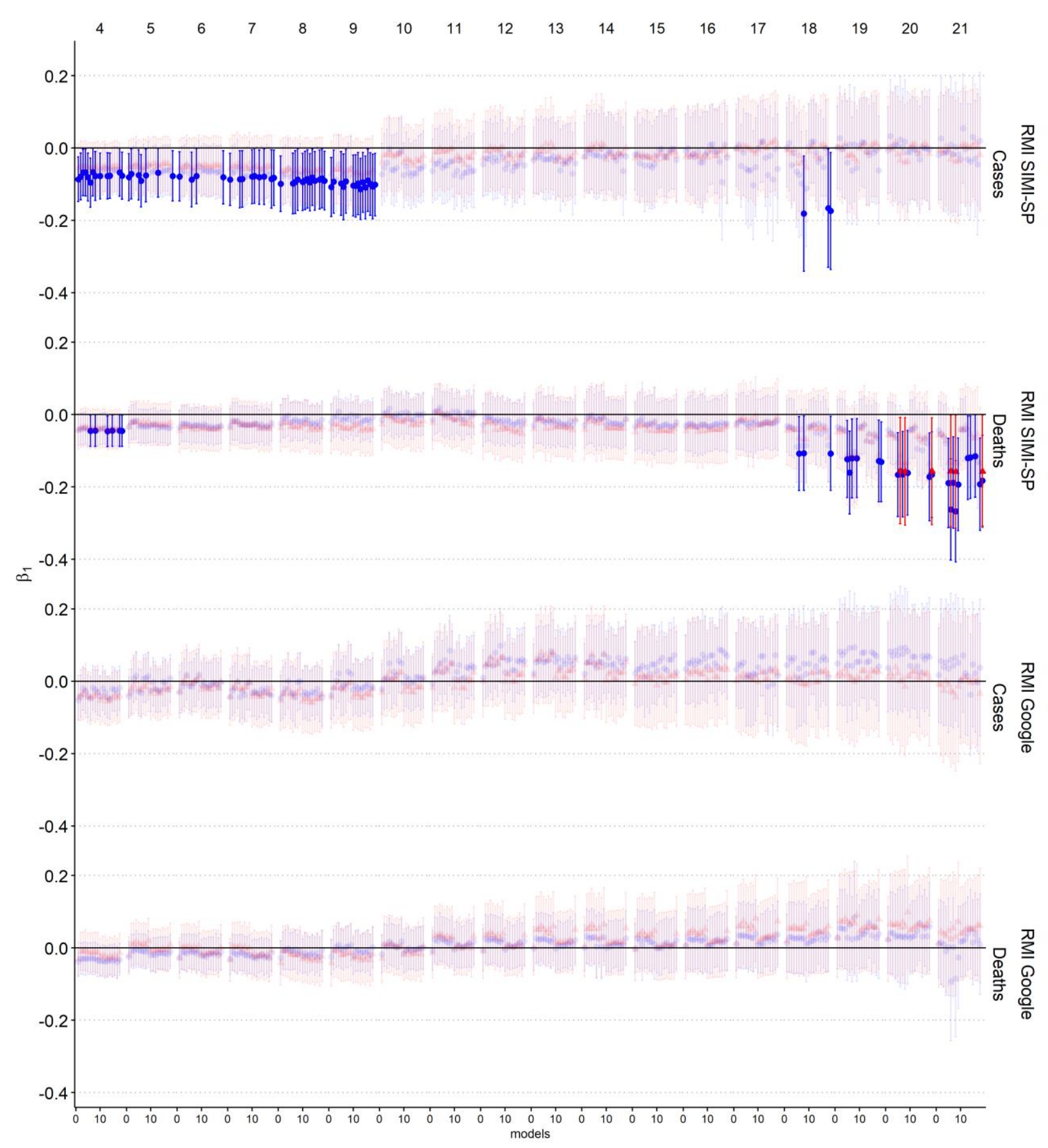

- Quasi Poisson - Negative Binomial

Figure 4. Coefficient of association between RMI SIMI-SP (\%) and Google (\%) and COVID-19 cases and deaths with a moving average of four to 21 days of delayed exposure with quasi-poisson and negative binomial distribution under different model configuration. $\beta_{1}$ non-significant associations ( $p$-value $>0.05$ ) are semi-transparent. 

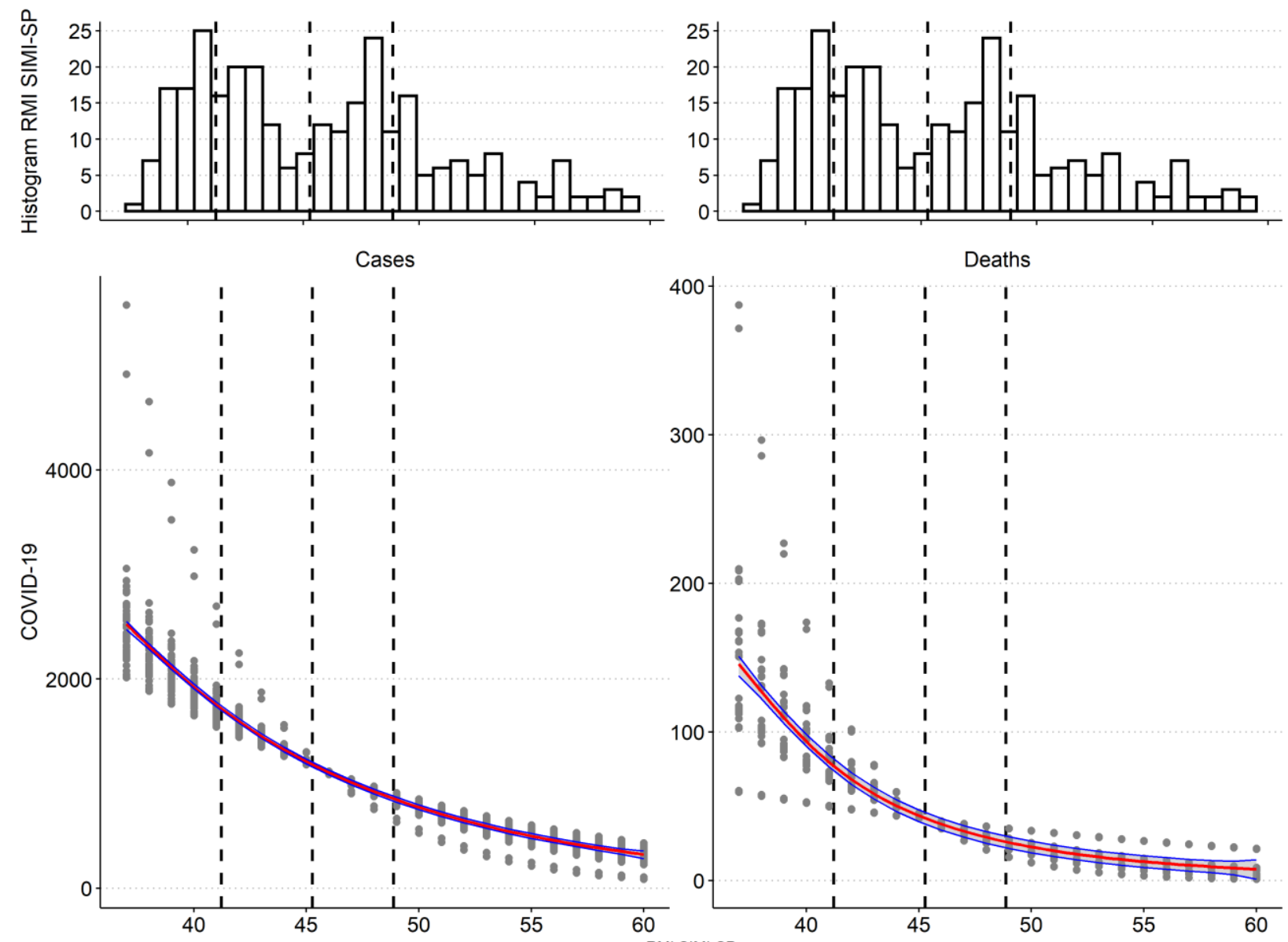

Cases

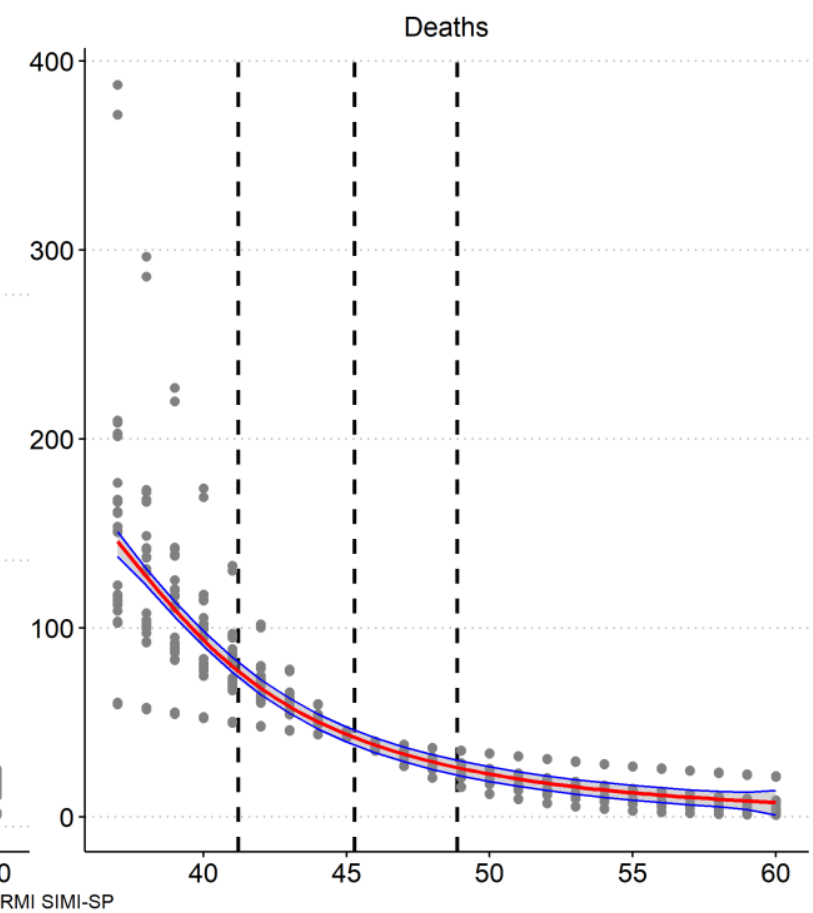

Figure 5. Association between COVID-19 cases and deaths and the percentage of RMI SIMI-SP (\%). The grey points show the association between COVID-19 and RMI after different periods of exposure. The red line represents the expected cases and deaths and blue lines upper and lower confidence intervals $95 \%$. The vertical black lines show the first quantile, median and third quantile of RMI SIMI-SP. The histograms of RMI SIMI-SP are repeated. 
medRxiv preprint doi: https://doi.org/10.1101/2021.02.08.21250113; this version posted August 3, 2021. The copyright holder for this preprint (which was not certified by peer review) is the author/funder, who has granted medRxiv a license to display the preprint in perpetuity.

\section{It is made available under a CC-BY 4.0 International license.}

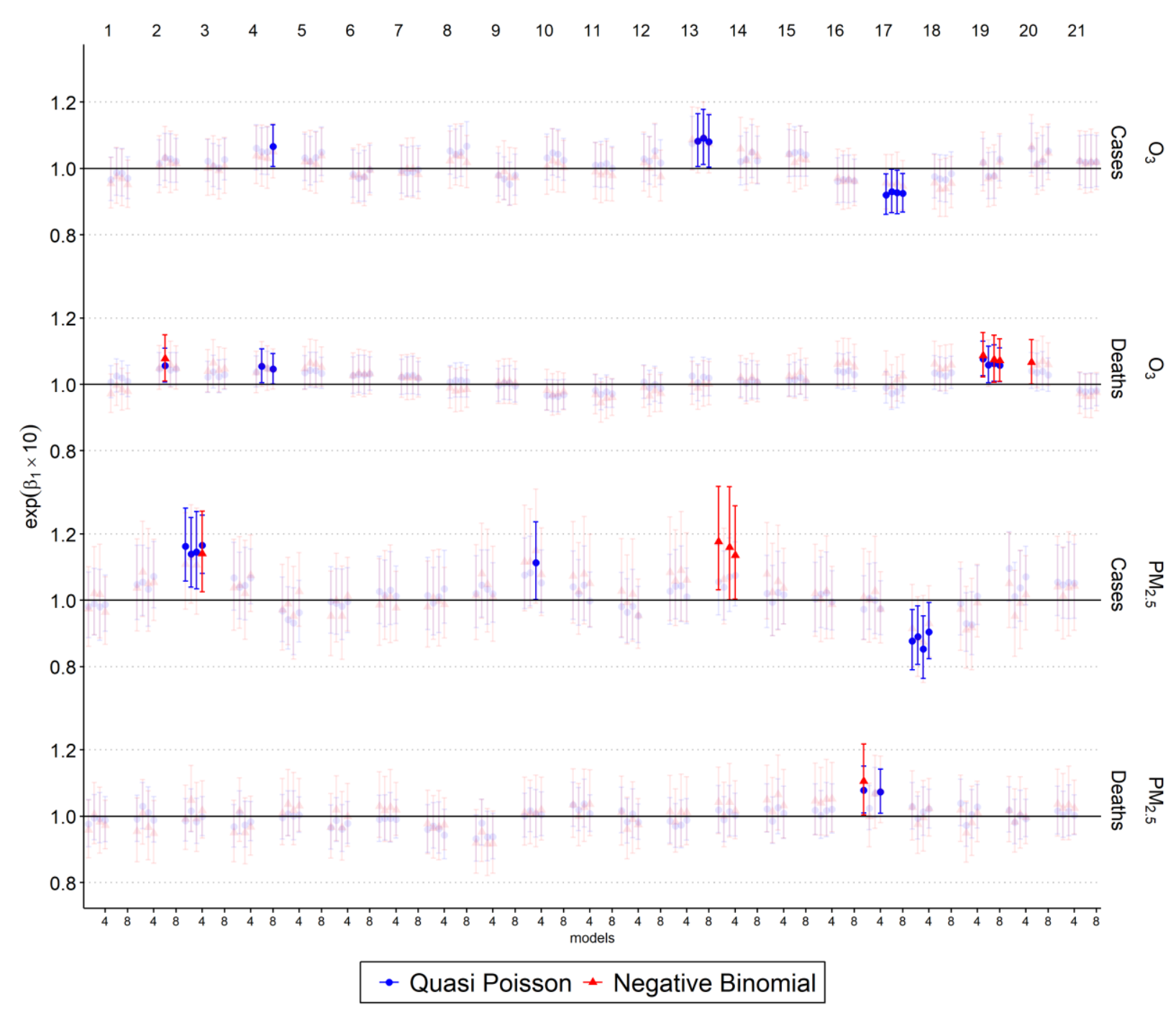

Figure 6. The relative risks of COVID-19 cases and deaths due to $10 \mu \mathrm{g} \cdot \mathrm{m}^{-3}$ of $\mathrm{PM}_{2.5}$ and $\mathrm{O}_{3}$ after $1-21$ days of exposure with single-lag models. $\beta_{1}$ non-significant associations (p-value $>0.05$ ) are semi-transparent. 